\title{
2. Fiji journalism pioneer remembers: Vijendra Kumar
}

CAN YOU start by telling me about your heritage?

I'm a third generation Fiji-Indian. I was born in Nadi, Fiji. I was educated in Fiji. I did some courses in journalism outside Fiji-at the East-West Centre in Hawaii and also in Berlin, Germany.

When did you start working at The Fiji Times?

I joined The Fiji Times as a reporter in 1969. After a couple of years I was made bureau chief. Then I was transferred to Suva and made news editor. From news editor, I became editor in 1975.

What was it like working for the paper at that time?

It was very exciting because I was the first local Indian to be employed by The Fiji Times as a reporter. Since I was based in Lautoka it gave me a lot of opportunities to chase all sorts of stories that didn't normally get in The Fiji Times before then. It gave me a very wide area to cover all sorts of news.

What did that range include?

Court reporting, local council, political meetings, political rallies, industrial actions by trade unions - virtually everything that happened in my area I covered.

You became editor in 1975. What was the political situation like then?

In 1975, the Alliance Government was in power and had been in power since before independence. From 1975 onwards, Fiji was on the march. There was political stability and there was a Government policy of promoting racial harmony and peace. Everyone seemed to think that racial harmony was a solid basis for future development. Things were going well — the economy was booming, tourism was booming and Fiji was quite a nice place to live. There was a lot of investment flowing in, especially in the tourism sector.

Ratu Sir Kamisese Mara was the Prime Minister. He was recognised internationally as a moderate leader and he was generally held in very high regard in Fiji as well. The Opposition was led by the National Federation Party, which was largely made up of Indian support but with a sprinkling of support from other communities - the Fijians and the part-Europeans and so on. 


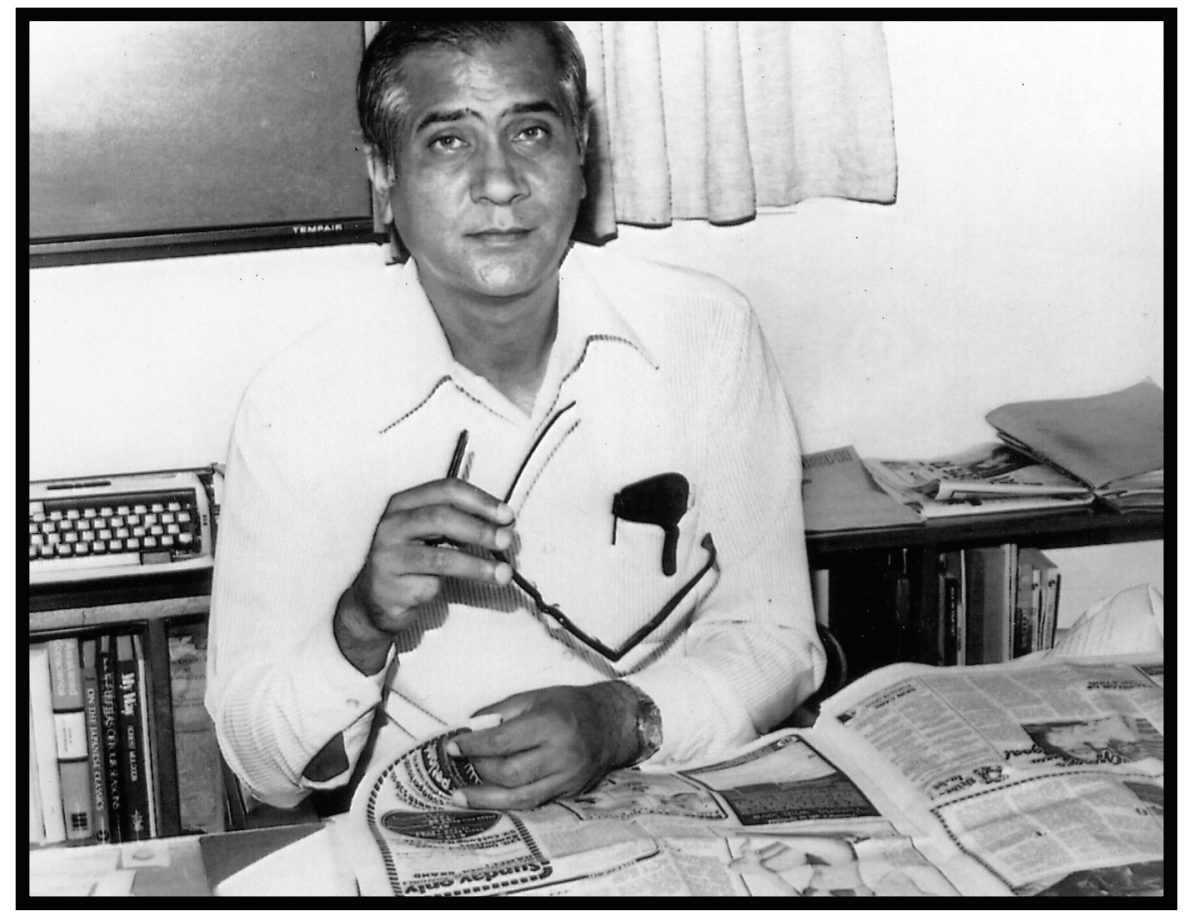

Vijendra Kumar: '[Local journalists] were far more clued up.'

When did you first hear about the coup in 1987? Where were you?

On 14 May 1987, I was actually driving away from Suva for a weekend holiday at Rakiraki. I had the car radio switched on to Radio Fiji and just as I reached Korovo, a town after Nausori about 50 or $60 \mathrm{~km}$ from Suva, the announcement came over [the air] that we should await a special announcement. And then Rabuka came on the air and announced that he had staged a coup and taken over the Government. That's how I heard of the coup.

And of course, I turned around and went straight back to Suva. By then our reporters had started gathering all the information that they could. So we were able to produce the next day's newspaper, the Saturday edition. And then after that we were shut down.

How long was the paper closed down?

After the May 14 coup, we were shut down for two to three weeks. I can't remember exactly how long. 
Were your journalists still covering the situation?

We were barred from our newsroom-locked out of the premises. But we still kept tabs on things. We met every day and whatever was happening we kept track of it.

Can you remember the arrival of the international media?

The first one to break the news on the international scene was Jim Shrimpton. He was the AAP man based in Suva. So he was the first one to send a flash out before the army got in and started unplugging all the telephone lines.

Then over the next three or four days, the first to arrive were a lot of Australian journalists - then New Zealand journalists. And then as the news spread around the world we had journalists from other places. We had Americans, Canadians and Hawaiians. And of course the correspondents for British newspapers based in Australia also flew in.

Did the presence of the international media have any impact on the local media?

No. Because the local media was already shut down and the radio station [Radio Fiji] was in the hands of the army, so they couldn't broadcast anything freely. What did happen was that the local journalists, who were far more clued up on what was happening, became a sort of conduit of information for all the foreign journalists. A lot of them would come and talk to us and get background information and find possible contacts to talk to. That was how they went about getting their information.

How much did the international media know about Fiji?

They had absolutely no idea. Very few of them knew very much about Fiji, except that it was a South Sea island where they went for a holiday. Very few of them knew much about the political system or the names of the leaders. So it was a surprise for us, and I think it was a big learning experience for the Australian and New Zealand journalists. The New Zealand journalists had a little bit more knowledge about Fiji than the Australians, because New Zealand had closer contacts with Fiji. Fiji got a lot of coverage on New Zealand radio and in New Zealand newspapers even before the coup. But Australian newspapers never reported anything that happened in Fiji as far as I remember, unless it was something sensational.

In a way, the international media were lucky that the local media were unable to report? 
Well, yes. Our hands were tied but they had quite a bit of freedom, at least for the first week. They were able to telex their stories through or phone their stories through. Then, of course, the army censors got in on the act and hey shut down all the lines. [The journalists] had difficulties sending stories after that.

Would you say that without the assistance of the local media, the international media would have been really struggling?

Yes. They had absolutely no idea who to talk to. One of our reporters arranged for a Melbourne Herald reporter to interview Colonel Rabuka. ${ }^{6}$ Rabuka wanted to talk to the press as much as he could, but he was still being selective. He wanted to put his case to the world, particularly the Australian and New Zealand media, whose governments were opposed to the coup.

Did you see any of the coverage by the international media?

Not much, because I didn't get any Australian newspapers in Fiji. But some of the copy that was filed through our offices I had a chance to look at, especially the copy filed by the News Ltd journalists. They were not bad, largely because of the cooperation from us. I think they were a little bit more on the ball than the others, who did not have that kind of resource to fall back on.

Were the international media able to access a wide range of sources?

Not really. For example, they were not able to get hold of the Opposition people. I don't think any of them were able to get hold of Dr [Timoci] Bavadra, for example, and have a full interview with him. They were able to talk to Rabuka and a few other Ministers in his military government. Some of them did go out into the villages and into the rural areas to try and gauge the reaction from the people. I think they got a mixed bag of reactions.

Do you think the local media learned anything from the international media? Was it a two-way learning experience?

I can't say that. The overseas media, of course, were far more aggressive and they had no idea of local protocol or sensitivities. Some of them really got into some pretty tight situations with the army fellahs. The local media, if we'd been free to report and publish things, would have taken a slightly different approach. We would have respected the protocols and sensitivities of people involved, and still go ahead and report what was worth reporting.

What was your overall impression of the international media?

My impression of the foreign journalists was that they had a very slim idea of what Fiji was about - about our political system, about the reasons for 236 PACIFIC JOURNALISM REVIEW 11 (2) 2005 
the coup, about the racial makeup of the country, about the land situationthey had no idea about all of these things. Most of them were expecting to see violent demonstrations and upheavals of the worst kind. I think quite a few of them were disappointed there was no bloodshed.

Do you think that if they understood Fiji a little better, that it might have had an impact on Fiji in the long run?

Yes, definitely. I think so. If these journalists had a little more knowledge about Fiji's complex political situation and the undercurrent of tension that had always been there, I think it might have had a different sort of impact on world opinion.

\section{References}

${ }^{1}$ For details of Rabuka's military service, see Dean, E., and Ritova, S. (1987). Rabuka: No other way. Sydney: Doubleday.

${ }^{2}$ Two local newspapers, The Fiji Times and The Fiji Sun, were closed down following editorials critical of the coup published on May 15- the day after the coup. News broadcast by Radio Fiji was monitored by military censors. There was no local television network in 1987.

${ }^{3}$ The only Australian journalist deported in 1987 was Trevor Watson of Australia's Radio National. Watson believes coup leaders deported him for two reasons: he helped broadcast a secretly taped message from the imprisoned Dr Bavadra; and Radio National could be picked up on short wave radio within Fiji, and was therefore more of a concern for coup leaders.

${ }^{4}$ A TV station in New Zealand showed footage of tanks in the streets of Suva. The problem was that the Fijian military didn't have any tanks. The footage was obviously from somewhere else. They also showed images of the partially destroyed ANZ Bank in Suva. These images turned out to be taken during recent renovations to the building. From: Thomson, P. (1999). Kava in the blood. Auckland, NZ: Tandem Press.

${ }^{5}$ The Minister of Information in Rabuka's cabinet was the late Dr Ahmed Ali.

${ }^{6}$ The Melbourne Herald reporter was Lynne Cossar, who was criticised for her coverage. See Robie, D. (1989). Blood on their banner: Nationalist struggles in the South Pacific. Sydney: Pluto Press, p. 227.

Anthony Mason is a University of Canberra PhD student who is researching Australian media coverage of the Fiji coups in May 1987 and May 2000. He has interviewed many Australian journalists who covered the coups for organisations, including ABC Radio and TV, Radio Australia, Australian Associated Press, Agence France Presse, The Australian and The Sydney Morning Herald. a.mason@student.canberra.edu.au 
Copyright of Pacific Journalism Review is the property of Auckland University of Technology and its content may not be copied or emailed to multiple sites or posted to a listserv without the copyright holder's express written permission. However, users may print, download, or email articles for individual use.

http://Mww.aut.ac.nz/depts/commstud/journ/pjrsubs.shtml 